\title{
A pharmacokinetic model to study the excretion of trichloroethylene and its metabolites after an inhalation exposure
}

\author{
AKIO SATO, TAMIE NAKAJIMA, YUKIKO FUJIWARA, AND \\ NINZO MURAYAMA \\ Department of Hygiene, Shinshu University Faculty of Medicine, Matsumoto, Japan
}

ABSTRACT For a better understanding of absorption, distribution, excretion, and metabolism of trichloroethylene the time-course of blood concentration of the vapour and urinary excretion of its metabolites was examined using a pharmacokinetic model. After a single experimental exposure in which four men inhaled 100 parts per million ( $\mathrm{ppm})$ of trichloroethylene for four hours an elimination curve showed three exponential components, that is, $x=1.005 \mathrm{e}^{-16.71 t}+0.449 \mathrm{e}^{-1.710 t}+$ $0.255 \mathrm{e}^{-0.2027 t}$, where $\mathrm{x}$ is the blood concentration in $\mathrm{mg} / \mathrm{l}$ and $\mathrm{t}$ the time in hours from 0 to 10 . The overall rate constant for the disappearance of trichloroethylene was found to agree with the theoretical one, estimated by means of a mathematical model for the blood concentration data. A $D_{\infty}-X_{\mathbf{D}}$ plot, developed from a mathematical model for urinary excretion, could also give a good estimate of rate constants for the transfer of trichloroethylene in the body. The rate constant thus estimated from urinary excretion was consistent with data on the blood concentration.

As industrial exposure to trichloroethylene vapour is liable to vary, air analysis does not necessarily give a real indication of the true exposure. A quantitative index of a worker's exposure can be estimated according to the amount of trichloroethylene being absorbed in his body (Roach, 1966; Elkins, 1967). Monitoring trichloroethylene levels in blood or expired air and measuring urinary metabolites of trichloroethylene are currently the most common techniques for determining the body burden of the vapour (Ahlmark and Forssman, 1951; Stewart et al., 1962, 1970, 1974; Morgan et al., 1970; Nomiyama, 1971; Ogata et al., 1971; Ertle et al., 1972; Ikeda et al., 1972; Müller et al., 1972, 1974; Pfäffli and Backman, 1972; Kimmerle and Eben, 1973; Lowry et al., 1974). Estimation and prediction of the body burden of trichloroethylene, however, require precise information on the absorption, distribution, excretion, and metabolism of the vapour in the human body. Such information, obtained from a single experimental exposure, would lead to knowledge of the transfer of trichloroethylene in the body in

Received for publication 2 February 1976 Accepted for publication 15 June 1976 chronic exposure, which is a common situation in a work place (Sato and Nakajima, 1977).

In the current study a mathematical model was developed to simulate the processes of absorption, distribution, excretion, and metabolism of trichloroethylene, the rate constants for each process being estimated from the time-course data of the vapour concentration in blood and the urinary excretion of its metabolites.

\section{Experiments}

\section{SOLUBILITY OF TRICHLOROETHYLENE IN} TISSUES OF RATS

The blood/air and tissue/blood partition coefficients were determined according to the method of Sato et al. (1974) with minor modifications. Tissue excised from a freshly killed rat was stripped of capsular and vascular connective tissues and weighed. The tissue was then homogenised with a known volume of $0.9 \%$ saline. Five vials of equal size, each $16.5 \mathrm{ml}$ on average and containing $1 \mathrm{ml}$ of the tissue homogenates, were used as test vessels. $0 \cdot 1 \mathrm{ml}$ of a trichloroethylene solution in saline containing $10 \mu \mathrm{l} / 1$ was put into the vials on which rubber and aluminium-foil stoppers were placed as quickly as 
possible. Five other vials were treated in a similar manner to act as controls except that in these, there were no tissue samples. Both the test and control vessels were kept at a temperature of $37^{\circ} \mathrm{C}$ in a thermoregulated water bath with a shaker for about two to six hours. After equilibration of trichloroethylene vapour between the test material and overlying air was achieved, $1 \mathrm{ml}$ of the gas phase was extracted by an air-tight syringe through the stopper and was introduced into a gas chromatograph. The tissue/air partition coefficient, which equals (concentration in tissue)/(concentration in air) by definition, was calculated from peak heights on the chromatogram in the same way as reported by Sato et al. (1974). The tissue/blood partition coefficient was expressed as the ratio of the tissue/air partition coefficient to the blood/air partition coefficient.

\section{EXPERIMENTAL HUMAN EXPOSURE TO} TRICHLOROETHYLENE

Four male Japanese medical students, 20 to 21years-old, and weighing on average $61.6 \mathrm{~kg}$, served as volunteers for the experiment in which they inhaled $100 \mathrm{ppm}$ of trichloroethylene for four hours. After cessation of exposure the concentration of trichloroethylene in blood and exhaled air and the amount of its urinary metabolites, that is, trichloroacetic acid (TCA), trichloroethanol (TCE), and total trichlorocompound (TTC), was measured and the time-course of these data was obtained.

\section{EXPOSURE CHAMBER}

Air for inhalation containing 100 ppm of trichloroethylene was prepared by passing it through liquid trichloroethylene in a gas-washing bottle at a known rate and diluting this saturated air with fresh air, flowing in with a metered volume of ventilation. Several preliminary tests showed that this simple method of atmosphere generation was satisfactory. The experimental exposure was as follows: The volunteers entered the exposure chamber of $12.5 \mathrm{~m}^{3}$ capacity in which there was no trichloroethylene. To achieve a rapid build-up to the required concentration, a predetermined amount of liquid trichloroethylene was injected through a rubber stopper attached to the monitoring window of the chamber at a sheet of gauze hung behind the window. The injected trichloroethylene was vaporised and mixed thoroughly by an electric fan. Several minutes after injection when the concentration had reached the required level, the air stream saturated with trichloroethylene $(21 / \mathrm{min})$ was introduced into the chamber, accompanied by a constant rate of ventilation which had been adjusted beforehand so as to maintain the desired concentration, $100 \mathrm{ppm}$, of trichloroethylene. An electric fan mounted on the chamber ceiling recirculated the air thus providing the homogenous exposure mixture. The atmospheric concentration was monitored by gas chromatography every 20 minutes during exposure.

\section{DETERMINATION OF TRICHLOROETHYLENE}

IN BLOOD AND EXHALED AIR

The examiner entered the chamber towards the end of the four hours' exposure and collected blood samples from cubital veins of each subject when his exposure had ceased. Immediately after leaving the chamber the subjects exhaled the end-tidal air into a $100 \mathrm{ml}$ glass syringe through an air tube attached to the end of the syringe. They held their breath for 10 seconds at a normal expiration, and then exhaled the residue into the syringe. Thereafter, blood and end-tidal air were collected at predetermined intervals for 10 hours. The concentration of trichloroethylene in blood was determined by a gas chromatographic equilibration method (Sato et al., 1975a). The concentration in exhaled air was measured by injecting a portion of the sampled air directly into a gas chromatograph with an air-tight syringe (Sato, 1968).

\section{DETERMINATION OF URINARY METABOLITES OF TRICHLOROETHYLENE}

The subjects had to collect all urine excreted at preselected intervals after exposure. TCA, TCE, and TTC were determined according to the method of Tanaka and Ikeda (1968).

\section{Results}

\section{SOLUBILITY OF TRICHLOROETHYLENE IN} BODY TISSUES OF RATS

The partition coefficients of trichloroethylene for various body tissues are shown in Table 1 , as well as those for triolein, cholesterol, lecithin, human blood, and human fat. The solubility coefficient of the vapour for fat is much higher than for other tissues: the tissue/blood partition coefficient was about 70 for fat, and 1-3 for most other tissues. The high solubility of trichloroethylene in fat compared with blood was also confirmed with human fat and blood. The fact that triolein has an extremely high affinity for trichloroethylene compared with lecithin and cholesterol suggests that fat content in the form of neutral fat in any tissue is a primary determinant for the level of solubility in that tissue. Fat tissue can be said therefore to play a very important role in the processes of absorption, distribution, and elimination of trichloroethylene. As in the case of other fat-soluble vapours such as benzene (FiserovaBergerova et al., 1974; Sato et al., 1974), toluene (Sato et al., 1974), and tetrachloroethylene (Guberan 
Table 1 Partition coefficients of trichloroethylene for various body tissues of rats

\begin{tabular}{|c|c|c|}
\hline & Mean & Standard deviation \\
\hline \multicolumn{3}{|l|}{ Five rats } \\
\hline Blood/air & $25 \cdot 82$ & $1 \cdot 70$ \\
\hline Lung/blood & 1.03 & $0 \cdot 17$ \\
\hline Heart/blood & $1 \cdot 10$ & 0.31 \\
\hline Kidney/blood & $1 \cdot 55$ & 0.48 \\
\hline Liver/blood & 1.69 & 0.37 \\
\hline Muscle/blood & 0.63 & 0.09 \\
\hline Brain/blood & $1 \cdot 29$ & 0.28 \\
\hline Testis/blood & 0.71 & $0 \cdot 12$ \\
\hline Spleen/blood & $1 \cdot 15$ & 0.20 \\
\hline Fat/blood & $25 \cdot 59$ & $1 \cdot 08$ \\
\hline \multicolumn{3}{|l|}{ Five determinations } \\
\hline Blood/air (human)1 & $9 \cdot 92$ & 0.63 \\
\hline Fat/air (human) ${ }^{2}$ & $674 \cdot 40$ & $34 \cdot 08$ \\
\hline Lecithin/air & 387.90 & 27.97 \\
\hline Cholesterol/air & $52 \cdot 15$ & $9 \cdot 59$ \\
\hline Cholesterol oleate/air & $261 \cdot 93$ & $35 \cdot 20$ \\
\hline Triolein/air & $848 \cdot 24$ & $31 \cdot 33$ \\
\hline
\end{tabular}

'Preserved blood from blood bank was used.

${ }^{2}$ The human fat tissue was obtained from a 23-year-old woman who died of acute myeloid leukaemia.

and Fernández, 1974), a three-compartment model can be applied to the transfer of trichloroethylene in the body, which is composed of (1) the tissue of the vessel-rich group (VRG) for example, brain, liver, kidney, etc.; (2) low perfused tissue of the muscle group (MG) for example, muscle and skin; and (3) poorly perfused tissue of the fat group (FG) for example, fat tissue and yellow bone marrow (Eger, 1963).

\section{EXPERIMENTAL HUMAN EXPOSURE TO TRICHLOROETHYLENE}

Elimination kinetics of trichloroethylene in blood The decrease of trichloroethylene concentration in blood and exhaled air with time is shown in Fig. 1. Each decay curve was resolved into three exponential components, using the general expression as follows:

$$
\mathrm{X}=\mathrm{A}_{1} \mathrm{e}^{-\alpha \cdot t}+\mathrm{A}_{2} \mathrm{e}^{-\alpha \cdot t}+\mathrm{A}_{3} \mathrm{e}^{-\alpha \cdot t},
$$

where $x$ is the concentration in $\mathrm{mg} / \mathrm{l}, \mathrm{t}$ the time in hours, and the values for $A_{i}$ and $\alpha_{i}(i=1,2$, and 3$)$ are shown in the figure.

Sato et al. (1974) reported that when a solvent reaches an apparent equilibrium throughout the entire body after a sufficient time has elapsed, the transfer of the vapour in the body can be simulated by the model in Fig. 2, where the whole body is treated as a single body mass. When this model is applied to trichloroethylene, its intake and output to and from the entire body can be expressed in the following differential equation:

$$
\mathrm{v} \frac{\mathrm{dx}}{\mathrm{d} \tau}=-\left(\lambda_{\mathrm{A}} \mathrm{a}+\mathrm{b}\right) \mathrm{x},
$$

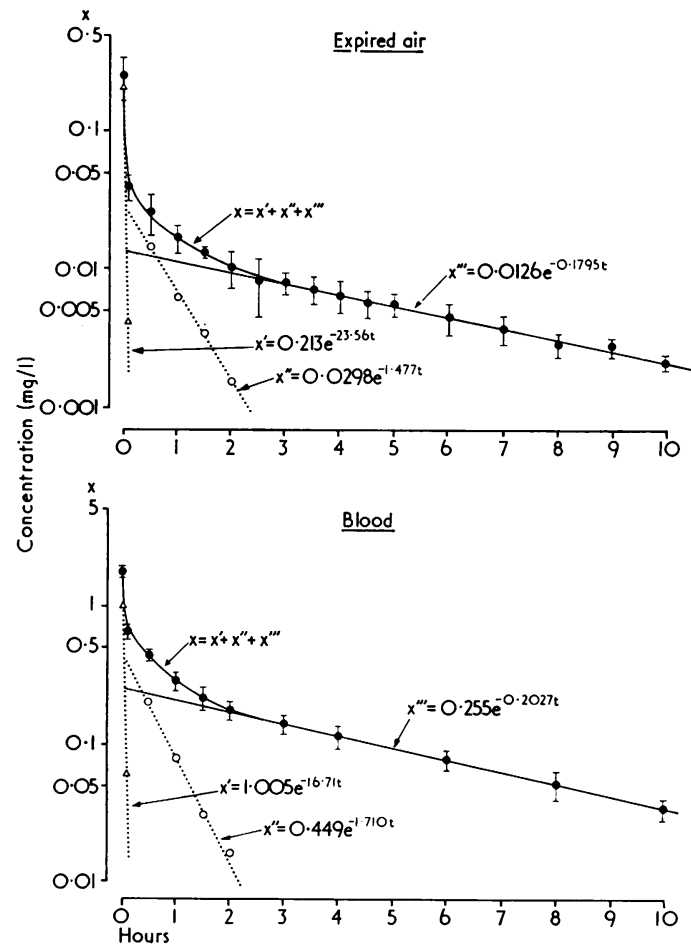

Fig. 1 Elimination curves of trichloroethylene.

where $\mathrm{V}$ is the distribution volume of trichloroethylene and $\tau$ equals the time elapsed after the trichloroethylene has reached apparent equilibrium period: In the equilibrium:

$$
\mathrm{V}=\lambda_{1} \mathrm{~V}_{1}+\lambda_{2} \mathrm{~V}_{2}+\lambda_{3} \mathrm{~V}_{3}
$$

Solving (2) for $\mathrm{x}$,

$$
\mathrm{x}=\mathrm{x}_{\mathrm{o}} \mathrm{e}-\frac{\lambda_{\mathrm{A}} \mathrm{a}+\mathrm{b}}{\mathrm{V}} \tau
$$

where $x_{0}$ is the concentration of trichloroethylene in blood just when it has reached the equilibrium, that is, $\tau=0$. From equation 3 , the rate constant for disappearance of trichloroethylene, $\left(\lambda_{\mathrm{A}} \mathrm{a}+\mathrm{b}\right) / \mathrm{V}$, becomes $\left(\lambda_{\mathrm{Aa}}+\mathrm{b}\right) /\left(\lambda_{1} \mathrm{~V}_{1}+\lambda_{2} \mathrm{~V}_{2}+\lambda_{3} \mathrm{~V}_{3}\right)$.

Assuming that the eventual rate constant, $\alpha_{3}$ in (1), is equal to this rate constant, we have

$$
\alpha_{3}=\frac{\lambda_{A} a+b}{\lambda_{1} V_{1}+\lambda_{2} V_{2}+\lambda_{3} V_{3}} .
$$

Since $\lambda_{3} V_{3} \gg \lambda_{1} V_{1}, \lambda_{2} V_{2}$ for trichloroethylene, equation 5 can be reduced to

$$
\alpha_{3}=\frac{\lambda_{\mathrm{A} a}+\mathrm{b}}{\lambda_{3} V_{3}}
$$

The metabolic clearance for trichloroethylene was unknown. Substituting the value in Table 2 for $\alpha_{3}$, a, $\lambda_{A}, \lambda_{3}$ and $V_{3}$ in (6) resulted in $b=104$. 


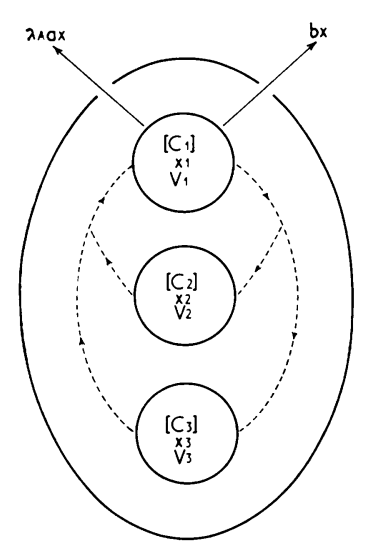

Fig. 2 A model for transfer of trichloroethylene in the body.

a : Alveolar ventilation, 1 /hour.

$\mathrm{b}$ : Metabolic clearance, 1 /hour.

$\left[\mathrm{C}_{1}\right]$ : Compartment composed of VRG.

$\left[\mathrm{C}_{2}\right]$ : Compartment composed of MG.

$\left[\mathrm{C}_{3}\right]$ : Compartment composed of FG.

$\mathrm{x}_{1}$ : Concentration in $\left[\mathrm{C}_{1}\right], \mathrm{mg} / \mathrm{l}$.

$\mathrm{x}_{2}$ : Concentration in $\left[\mathrm{C}_{2}\right], \mathrm{mg} / \mathrm{l}$.

$\mathrm{x}_{3}$ : Concentration in $\left[\mathrm{C}_{3}\right], \mathrm{mg} / \mathrm{l}$.

$\lambda_{\mathrm{A}}:$ Air/blood partition coefficient.

$\lambda_{1}:$ VRG/blood partition coefficient.

$\lambda_{2}:$ MG/blood partition coefficient.

$\lambda_{3}:$ FG/blood partition coefficient.

$\mathrm{V}_{1}$ : Volume of VRG, 1.

$\mathrm{V}_{2}$ : Volume of MG, 1 .

$\mathrm{V}_{3}$ : Volume of FG, 1.

Broken lines with arrows show blood flow through each compartment.

Table 2 Values used in the present model

\begin{tabular}{lc}
\hline $\mathrm{V}_{1}, 1$ & $8^{1}$ \\
$\mathrm{~V}_{2}, 1$ & $31^{1}$ \\
$\mathrm{~V}_{3}, 1$ & $10^{1}$ \\
$\mathrm{a}, 1$ /hour & $336^{1}$ \\
$\mathrm{~b}, 1$ /hour & $104^{2}$ \\
$\lambda_{\mathrm{A}}$ & $0 \cdot 1^{2}$ \\
$\lambda_{1}$ & $1 \cdot 5^{2}$ \\
$\lambda_{2}$ & $1 \cdot 0^{2}$ \\
$\lambda_{3}$ & $68^{2}$ \\
$a_{3}$, hour-1 & $0 \cdot 2027^{2}$ \\
\hline
\end{tabular}

${ }^{1}$ Cited from Sato et al. (1974).

${ }^{2}$ Results obtained in the current investigation.

\section{Excretion kinetics of urinary metabolites}

The time-courses of urinary excretion of TCA, TCE, and TTC are shown in Table 3. The cumulative amount of each metabolite was plotted against time as shown in Fig. 3.

The major metabolic pathway of trichloroethylene in a living body is generally considered to be as shown in Fig. 4 (Williams, 1959; Daniel, 1963; Byington and Leibman, 1965), where all the rate constants are assumed to be first-order rate constants. Let $X_{A}, X_{B}, X_{C}$, and $X_{D}$ be the amounts of $A, B, C$, and $D$, respectively, at time $t$ which equals the time that has elapsed after the cessation of the exposure. We then have for the model in Fig. 4,

$$
\begin{aligned}
\frac{d X_{A}}{d t} & =-\left(k_{1}+k_{4}\right) X_{A}, \\
\frac{d X_{B}}{d t} & =k_{1} X_{A}-\left(k_{2}+k_{i}+k_{j}\right) X_{B}, \\
\frac{d X_{C}}{d t} & =k_{2} X_{B}-k_{3} X_{C}, \\
\text { and } \frac{d X_{D}}{d t} & =k_{3} X_{C} .
\end{aligned}
$$

Solving (7) for $X_{A}$,

$X_{A}=A_{0} e^{-k_{A} t}$,

where $A_{o}$ is the amount of $A$ at $t=0$, and $k_{A}=$ $k_{1}+k_{4}$. ( $k_{A}$ is the overall rate constant for loss of $A$ from the body, and it has already been mentioned that $k_{A}$ will be equal to $\left(\lambda_{A} a+b\right) / V$, when trichloroethylene will have reached an apparent equilibrium.)

From (8), (9), and (11) we obtain

$\mathrm{X}_{\mathbf{C}}=\mathrm{Q}_{3} \mathrm{e}^{-\mathrm{k}_{\mathbf{3}} \mathrm{t}}-\mathrm{Q}_{2} \mathrm{e}^{-\mathrm{k}_{\mathbf{B}} \mathrm{t}}+\mathrm{Q}_{1} \mathrm{e}^{-\mathrm{k}_{\mathbf{A}} \mathrm{t}}$,

where $\mathbf{k}_{B}=\mathbf{k}_{2}+\mathbf{k}_{\mathbf{1}}+\mathbf{k}_{\mathbf{j}}\left(\mathrm{k}_{\mathrm{B}}\right.$ is the overall rate constant for loss of $B$ from the body.), $B_{o}$ and $C_{o}$ the amount of $\mathrm{B}$ and $\mathrm{C}$ at $\mathrm{t}=0$, respectively, and where

$$
\begin{aligned}
& Q_{1}=\frac{k_{1} k_{2}}{\left(k_{A}-k_{B}\right)\left(k_{A}-k_{3}\right)} A_{0}, \\
& Q_{2}=\frac{k_{2}}{k_{B}-k_{3}}\left(B_{0}+\frac{k_{1}}{k_{A}-k_{B}} A_{0}\right), \\
& \text { and } Q_{3}=C_{0}+\frac{k_{2}}{k_{B}-k_{3}} B_{0}+ \\
& \frac{k_{1} k_{2}}{\left(k_{B}-k_{3}\right)\left(k_{A}-k_{3}\right)} A_{0} .
\end{aligned}
$$

Substituting $X_{C}$ in (12) into (10),

$\frac{d X_{D}}{d t}=k_{3} Q_{3} e^{-k_{3} t}-k_{3} Q_{2} e^{-k_{B} t}+k_{3} Q_{1} e^{-k_{A} t}$

Solving (13) for $\mathrm{X}_{\mathrm{D}}$,

$X_{D}=D_{o}+C_{o}+\frac{k_{2}}{k_{B}} B_{0}+\frac{k_{1} k_{2}}{k_{A} k_{B}} A_{0}$

$-Q_{3} e^{-k_{3} t}+\frac{k_{3}}{k_{B}} Q_{2} e^{-k_{B} t}-\frac{k_{3}}{k_{A}} Q_{1} e^{-k_{A} t}$,

where $D_{0}$ is the amount of $D$ at $t=0$.

Let $D_{\infty}$ be the total amount of $D$, that is, the total 
amount of any one of TCA, TCE, or TTC excreted in urine, we have

$\mathrm{D}_{\infty}=\mathrm{k}_{3} \int_{0}^{\infty} \mathrm{X}_{\mathrm{Cdt}}=\mathrm{D}_{\mathrm{o}}+\mathrm{C}_{\mathrm{o}}+\frac{\mathrm{k}_{2}}{\mathrm{k}_{\mathrm{B}}} \mathrm{B}_{\mathrm{o}}+\frac{\mathrm{k}_{1} \mathrm{k}_{2}}{\mathrm{k}_{\mathrm{A}} \mathrm{k}_{\mathrm{B}}} \mathbf{A}_{\mathrm{o}}$.

The equation (14) can therefore be reduced to

$D_{\infty}-X_{D}=Q_{3} e^{-k_{3} t}-\frac{k_{3}}{k_{B}} Q_{2} e^{-k_{B} t}+\frac{k_{3}}{k_{A}} Q_{1} e^{-k_{A} t}$.

Since $k_{3} \ll k_{A}$ or $k_{B}$, we can see that when $D_{\infty}-\overline{X_{D}}$ is plotted on a logarithmic scale against time, the slope of the line drawn through the second half of the points will be $-k_{3}$. When this line extrapolated to $t=0$ and $\left|Q_{3} e^{-k_{3} t}-\left(D_{\infty}-X_{D}\right)\right|$ is replotted, the slope of the line drawn through the points at the tail end of this plot will give an estimate of the smaller one of the two rate constants, $\mathrm{k}_{\mathrm{A}}$ and $\mathrm{k}_{\mathrm{B}}$, and the slope determined from the residual points an estimate of the larger one (Fig. 5).

The $\mathrm{D}_{\infty}-\mathrm{X}_{\mathrm{D}}$ plots for TCA, TCE, and TTC resulted in the expressions as follows:

$$
\begin{aligned}
D_{\infty}-X_{D}(T C A)= & 113 \cdot 56 \mathrm{e}^{-0.0177 t}-59 \cdot 30 \mathrm{e}^{-0.0618 t} \\
& +16 \cdot 89 \mathrm{e}^{-0.2130 t} \\
\mathrm{D}_{\infty}-\mathrm{X}_{\mathrm{D}}(\text { TCE })= & 216 \cdot 23 \mathrm{e}^{-0.0285 t}+75 \cdot 23 \mathrm{e}^{-0.0961 t} \\
D_{\infty}-\mathrm{X}_{\mathrm{D}}(\text { TTC })= & 303 \cdot 24 \mathrm{e}^{-0.0224 t}-39 \cdot 44 \mathrm{e}^{-0.8009 t} \\
& +79 \cdot 34 \mathrm{e}^{-0.1890 t}
\end{aligned}
$$

The estimates of $k_{A}$ thus obtained from TCA- and TTC-plots agree generally with the eventual rate constant, $\alpha_{3}$ in (1), which was more directly determined from the time-course of blood or exhaled air concentration of trichloroethylene. The reason why the TCE-plot alone did not result in a three-exponential expression has not yet been fully elucidated, but may be due to the fact that the plotted values for TCA and TTC are directly measured but the value for TCE is indirectly estimated, being expressed as the difference between these values for TCA and TTC.

\section{Discussion}

The quantitative study of the time-course of absorption, distribution, excretion, and metabolism of toxic substances is a useful tool in studying the characteristics of toxic effects induced by them (Levy and Gibaldi, 1972; Sato et al., 1975b). The processes of uptake and washout of organic solvent vapours in a human body have recently been studied using an analogue or mathematical model, which simuiates the processes and gives an adequate prediction (Fiserova-Bergerova et al., 1974; Guberan and Fernández, 1974).

With few exceptions, most pharmacokinetic models have been built on the assumption that blood perfusion alone is an effective medium of transport for all tissues in a living body (Kety, 1951). The mathematical model based on this perfusionlimited assumption, failed to simulate the time-course of elimination of inhaled benzene and toluene in men (Sato et al., 1974). For the transfer of fat-soluble compounds direct diffusion between neighbouring tissues, each having different perfusion/partition properties and hence being filled and emptied at a different rate, was found to be a significant pathway in addition to perfusion (Perl et al., 1965). Taking account of this intertissue diffusion, we have assumed that it takes no longer than three hours after exposure has ceased for trichloroethylene to reach an

\begin{tabular}{|c|c|c|c|c|}
\hline \multirow{2}{*}{$\begin{array}{l}\text { Interval of measurements } \\
\text { (hours) }\end{array}$} & \multirow[t]{2}{*}{ Midtime (hour) } & \multicolumn{3}{|c|}{ Amount measured $(\mathrm{mg})$ mean $\pm S D$} \\
\hline & & $T C A$ & $T C E$ & $T T C$ \\
\hline $\begin{array}{c}0-1 \\
1-2 \\
2-4 \\
4-8 \\
8-12 \\
12-16 \\
16-24 \\
24-36 \\
36-48 \\
48-60 \\
60-72 \\
72-84 \\
84-96 \\
96-108 \\
108-120 \\
120-132 \\
132-144 \\
144-156 \\
156-168 \\
168-180\end{array}$ & $\begin{array}{r}0.5 \\
1.5 \\
3.0 \\
6.0 \\
10.0 \\
14.0 \\
20.0 \\
30.0 \\
42.0 \\
54.0 \\
66.0 \\
78.0 \\
90.0 \\
102.0 \\
114.0 \\
126.0 \\
138.0 \\
150.0 \\
162.0 \\
174.0\end{array}$ & $\begin{array}{l}0.21 \pm 0.18 \\
0.25 \pm 0.08 \\
0.57 \pm 0.27 \\
2.37 \pm 1.57 \\
1.32 \pm 0.61 \\
0.93 \pm 0.26 \\
2.15 \pm 0.74 \\
4.32 \pm 1.31 \\
8.17 \pm 3.05 \\
7.79 \pm 1.84 \\
7.83 \pm 1.48 \\
6.95 \pm 2.64 \\
4.34 \pm 0.91 \\
4.56 \pm 1.22 \\
3.32 \pm 0.93 \\
3.23 \pm 1.18 \\
4.00 \pm 2.30 \\
2.44 \pm 0.32 \\
1.44 \pm 0.53 \\
2.55 \pm 0.32\end{array}$ & 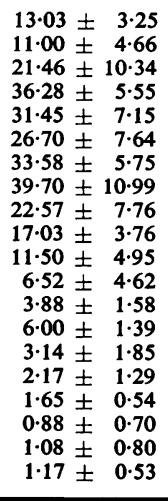 & 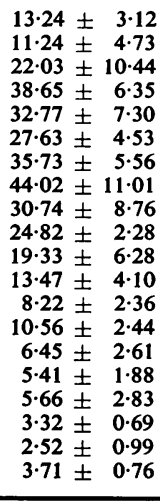 \\
\hline
\end{tabular}
apparent equilibrium and then to be distributed throughout the body according to its partitioning characteristics between blood and

Table 3 Urinary excretion of TCA, TCE, and TTC 


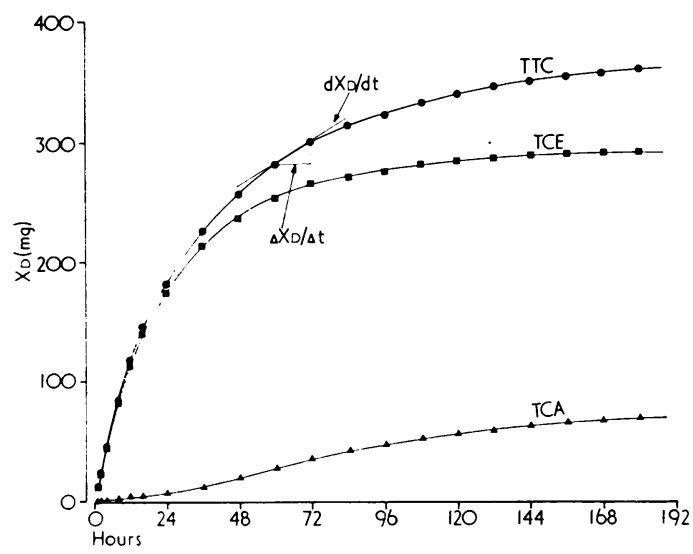

Fig. 3 Cumulative amount of metabolites excreted in urine.

tissues. The value of $104 \mathrm{1} /$ hour for metabolic clearance was estimated by treating the whole body in the equilibrium as a single body mass. So far there is no proof for these assumptions, but they would be supported indirectly if the quantities predicted agreed with the quantities measured by other methods. About $70-80 \%$ of the absorbed trichloroethylene was reported to be excreted in urine as metabolites and the remaining $20-30 \%$ to be eliminated unchanged in expired air (Bartoniček, 1962; Nomiyama and Nomiyama, 1971; Ogata et al., 1971). Assuming that the loss of trichloroethylene absorbed in man through other pathways is negligible, the ratio, $\mathbf{P}$, of the amount metabolised to the total amount absorbed is given as follows:

$$
\begin{aligned}
\mathbf{P}= & \frac{\text { amount metabolised }}{\text { total amount absorbed }}=\frac{b x}{\left(\lambda_{A} a+b\right) x} \\
& \frac{b}{\lambda_{A} a+b}
\end{aligned}
$$

Substitution of $b=104$ for $b$ in (16) resulted in $P=$ $0 \cdot 75$, which is not very different from the one measured more directly by other investigators. Therefore, the assumptions that trichloroethylene

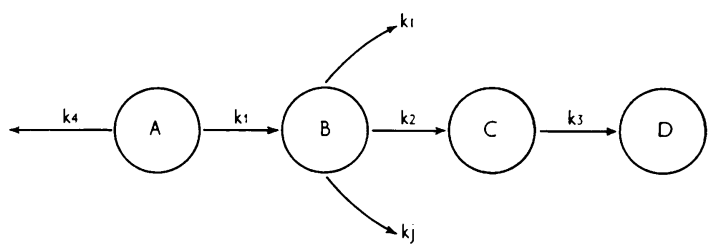

Fig. 4 Metabolic pathways of trichloroethylene.

A : Trichloroethylene in the body.

B : A metabolite of trichloroethylene in the body, possibly chloral hydrate.

C : A metabolite of trichloroethylene in the body, which is to be excreted and applies to any one of TCA, TCE, and TTC.

D : C excreted in urine (TCA, TCE, or TTC).

$k_{1}$ : Rate constant for the step $A \rightarrow B$, which is another quantity from the metabolic clearance $b$ in Fig. 1.

$\mathbf{k}_{2}$ : Rate constant for the step $\mathrm{B} \rightarrow \mathrm{C}$.

$k_{3}$ : Rate constant for the step $C \rightarrow D$.

$\mathbf{k}_{\mathbf{4}}$ : Rate constant for the loss of $A$ through other pathways than $A \rightarrow B$. ( $k_{4}$ corresponds approximately to the elimination through the lungs, but is not identical to a in Fig. 1.)

$\mathbf{k}_{\mathbf{i}}, \mathbf{k}_{\mathbf{j}}$ : Rate constant for the pathways for disposal of $B$ other than the $\mathrm{B} \rightarrow \mathrm{C}$ step.

\begin{tabular}{|c|c|c|c|c|c|c|c|c|c|c|c|}
\hline \multicolumn{3}{|c|}{$\Delta X_{\mathrm{D}} / \Delta t, \mathrm{mg} / \mathrm{hour}$} & \multicolumn{3}{|l|}{$X_{\mathrm{D}}, m g$} & \multicolumn{3}{|c|}{$D_{\infty}-X_{\mathrm{D}}, m g$} & \multicolumn{3}{|c|}{$\left|Q_{3} e^{-k_{3} t}-\left(D_{\infty}-X_{\mathrm{D}}\right)\right|, m g$} \\
\hline$T C A$ & $T C E$ & $T T C$ & $T C A$ & $T C E$ & $T T C$ & $T C A$ & $T C E$ & $T T C$ & $T C A$ & $T C E$ & $T T C$ \\
\hline $0 \cdot 21$ & 13.03 & $13 \cdot 24$ & $0 \cdot 21$ & 13.03 & $13 \cdot 24$ & $68 \cdot 51$ & $277 \cdot 74$ & $346 \cdot 25$ & 43.06 & $67 \cdot 59$ & $49 \cdot 73$ \\
\hline $0 \cdot 25$ & $11 \cdot 00$ & $11 \cdot 24$ & 0.45 & $24 \cdot 02$ & $24 \cdot 48$ & $68 \cdot 25$ & $266 \cdot 75$ & $335 \cdot 01$ & $41 \cdot 36$ & $62 \cdot 50$ & 45.06 \\
\hline $0 \cdot 29$ & $10 \cdot 74$ & $11 \cdot 02$ & 1.02 & $45 \cdot 48$ & $46 \cdot 53$ & 67.69 & $245 \cdot 29$ & $312 \cdot 98$ & $38 \cdot 12$ & $52 \cdot 35$ & $35 \cdot 74$ \\
\hline 0.60 & $9 \cdot 07$ & $9 \cdot 67$ & $3 \cdot 39$ & $81 \cdot 76$ & $85 \cdot 18$ & $65 \cdot 33$ & $209 \cdot 01$ & $274 \cdot 33$ & $33 \cdot 25$ & $36 \cdot 84$ & $20 \cdot 86$ \\
\hline 0.33 & $7 \cdot 87$ & $8 \cdot 19$ & $4 \cdot 71$ & $113 \cdot 20$ & $117 \cdot 90$ & $64 \cdot 00$ & $177 \cdot 56$ & $241 \cdot 57$ & $27 \cdot 85$ & 23.93 & $9 \cdot 83$ \\
\hline 0.23 & 6.68 & 6.91 & $5 \cdot 64$ & $139 \cdot 91$ & $145 \cdot 53$ & 63.08 & 150.87 & 213.94 & $22 \cdot 50$ & $13 \cdot 78$ & $2 \cdot 07$ \\
\hline 0.27 & $4 \cdot 20$ & $4 \cdot 47$ & $7 \cdot 79$ & 173.49 & $181 \cdot 27$ & 60.93 & $117 \cdot 29$ & $178 \cdot 21$ & $13 \cdot 36$ & $8 \cdot 13$ & $1 \cdot 11$ \\
\hline 0.36 & $3 \cdot 31$ & 3.67 & $12 \cdot 11$ & $213 \cdot 18$ & $225 \cdot 29$ & $56 \cdot 61$ & $77 \cdot 59$ & $134 \cdot 19$ & & & \\
\hline 0.68 & $1 \cdot 88$ & $2 \cdot 56$ & $20 \cdot 28$ & $235 \cdot 76$ & $256 \cdot 03$ & 48.44 & 55.02 & 103.45 & & & \\
\hline 0.65 & 1.42 & $2 \cdot 07$ & 28.06 & $252 \cdot 79$ & $280 \cdot 85$ & 40.65 & $37 \cdot 99$ & $78 \cdot 64$ & & & \\
\hline 0.65 & 0.96 & 1.61 & $35 \cdot 89$ & $264 \cdot 29$ & $300 \cdot 17$ & 32.83 & 26.49 & $59 \cdot 31$ & & & \\
\hline 0.58 & 0.54 & $1 \cdot 12$ & $42 \cdot 84$ & 270.81 & $313 \cdot 64$ & $25 \cdot 88$ & $19 \cdot 97$ & $45 \cdot 84$ & & & \\
\hline 0.36 & 0.32 & 0.68 & $47 \cdot 18$ & $274 \cdot 68$ & $321 \cdot 86$ & $21 \cdot 54$ & 16.09 & $37 \cdot 62$ & & & \\
\hline 0.38 & 0.50 & 0.88 & $51 \cdot 74$ & 280.68 & $332 \cdot 42$ & 16.98 & 10.09 & $27 \cdot 07$ & & & \\
\hline 0.28 & 0.26 & 0.54 & 55.05 & $283 \cdot 82$ & $338 \cdot 87$ & $13 \cdot 66$ & 6.95 & $20 \cdot 61$ & & & \\
\hline 0.27 & 0.18 & 0.45 & $58 \cdot 29$ & $285 \cdot 99$ & $344 \cdot 28$ & 10.43 & $4 \cdot 78$ & $15 \cdot 21$ & & & \\
\hline 0.33 & $0 \cdot 14$ & 0.47 & $62 \cdot 29$ & $287 \cdot 64$ & $349 \cdot 93$ & 6.43 & $3 \cdot 13$ & 9.55 & & & \\
\hline $0 \cdot 20$ & 0.07 & 0.28 & $64 \cdot 73$ & $288 \cdot 53$ & $353 \cdot 25$ & 3.99 & $2 \cdot 25$ & $6 \cdot 23$ & & & \\
\hline $0 \cdot 12$ & 0.09 & 0.21 & $66 \cdot 16$ & $289 \cdot 61$ & $355 \cdot 77$ & $2 \cdot 55$ & $1 \cdot 17$ & $3 \cdot 71$ & & & \\
\hline $0 \cdot 21$ & $0 \cdot 10$ & 0.31 & $68 \cdot 71^{1}$ & $290 \cdot 77^{1}$ & $359 \cdot 48^{1}$ & 0 & 0 & 0 & & & \\
\hline
\end{tabular}

Table 3 Urinary excretion of TCA, TCE, and TTC

The value is equal to $D_{\infty}$. 


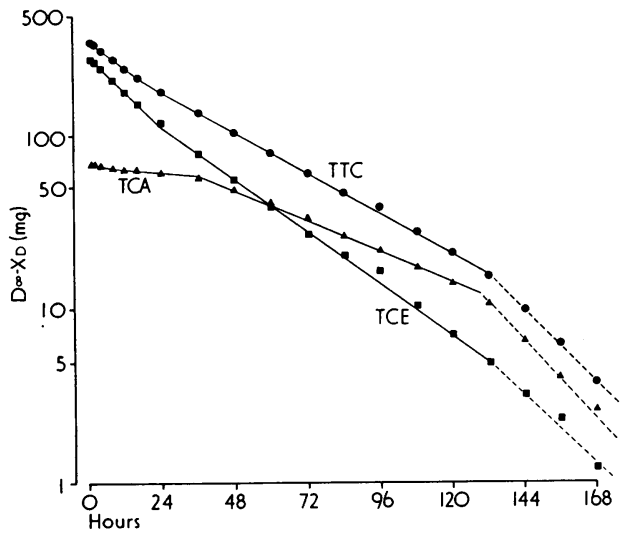

Fig. 5 Semilogarithmic plots of $\mathrm{D}_{\infty}-\mathrm{X}_{\mathrm{D}}$.

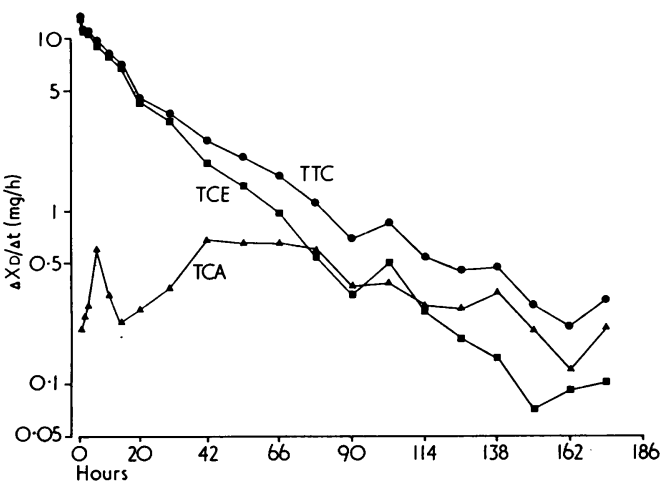

Fig. 6 Semilogarithmic plots of $\Delta X_{\mathrm{D}} / \Delta t$ against midpoint time.

will have reached an apparent equilibrium throughout the body in three hours after exposure has ceased and that the whole body can then be treated as a single body mass, should not be unreasonable. The rate constants for the disappearance of trichloroethylene estimated from the time-courses of urinary excretion of TCA and TTC based on these assumptions agreed with those determined from the timecourse of blood concentration of trichloroethylene.

The method of estimating rate constants for absorption, metabolism, and elimination of drugs from urinary excretion data was reported by Wagner (1967). The method described above applies Wagner's method for trichloroethylene with several modifications. As is clear in (13), the plot of $\mathrm{dX}_{\mathrm{D}} / \mathrm{dt}$ on a semilogarithmic scale against time is also expected to give an estimate of $k_{3}, k_{B}$, and $k_{A}$. The value of $\Delta \mathrm{X}_{\mathrm{D}} / \Delta \mathrm{t}$ in Table 3 , an estimate of $\mathrm{dX} \mathrm{D} / \mathrm{dt}$, was plotted on a semilogarithmic paper (Fig. 6). Com- parison of the $D_{\infty}-X_{D}$ plot (Fig. 5) and $\Delta X_{D} / \Delta t$ plot (Fig. 6), shows that the former is clearly more linear.

TCA accounts for about $20 \%$ of TTC, and TCE for about $80 \%$ in the present single exposure as is shown in Table 3. The fact that $k_{3}$ for TCA is smaller than that for TCE, however, suggests that TCA has a longer biological half-life than TCE, which will lead to the prediction that the proportion of urinary metabolites excreted as TCA increases in a chronic exposure (Sato and Nakajima, 1977).

\section{References}

Ahlmark, A., and Forssman, S. (1951). Evaluating trichloroethylene exposures by urinalyses for trichloroacetic acid. Archives of Industrial Hygiene and Occupational Medicine, 3, 386-398.

Bartoniček, V. (1962). Metabolism and excretion of trichloroethylene after inhalation by human subjects. British Journal of Industrial Medicine, 19, 134-141.

Byington, K. H., and Leibman, K. C. (1965). Metabolism of trichloroethylene in liver microsomes. II. Identification of the reaction products as chloral hydrate. Molecular Pharmacology, 1, 247-254.

Daniel, J. W. (1963). The metabolism of ${ }^{36} \mathrm{Cl}$-labelled trichloroethylene and tetrachloroethylene in the rat. Biochemical Pharmacology, 12, 795-802.

Eger, E. I. II (1963). A mathematical model of uptake and distribution. In Uptake and Distribution of Anesthetic Agents, pp. 72-87. Edited by E. M. Papper and R. J. Kitz. McGraw-Hill: New York.

Elkins, H. B. (1967). Excretory and biologic threshold limits. American Industrial Hygiene Association Journal, 28, 305308.

Ertle, T., Henschler, G., Müller, G., and Spassovski, M. (1972). Metabolism of trichloroethylene in man. I. The significance of trichloroethanol in long-term exposure conditions. Archiv für Toxikologie, 29, 171-188.

Fiserova-Bergerova, V., Vlach, J., and Singhal, K. (1974). Simulation and prediction of uptake, distribution, and exhalation of organic solvents. British Journal of Industrial Medicine, 31, 45-52.

Guberan, E., and Fernández, J. (1974). Control of industrial exposure to tetrachloroethylene by measuring alveolar concentrations: theoretical approach using a mathematical model. British Journal of Industrial Medicine, 31, 159-167.

Ikeda, M., Ohtsuji, H., Imamura, T., and Komoike, Y. (1972). Urinary excretion of total trichloro-compounds, trichloroethanol, and trichloroacetic acid as a measure of exposure to trichloroethylene and tetrachloroethylene. British Journal of Industrial Medicine, 29, 328-333.

Kety, S. S. (1951). The theory and applications of the exchange of inert gas at the lungs and tissues. Pharmacological Reviews, 3, 1-41.

Kimmerle, G., and Eben, A. (1973). Metabolism, excretion and toxicology of trichloroethylene after inhalation. 2. Experimental human exposure. Archiv für Toxikologie, 30, 127-138.

Levy, G., and Gibaldi, M. (1972). Pharmacokinetics of drug action. Annual Review of Pharmacology, 12, 85-98.

Lowry, L. K., Vandervort, R., and Polakoff, P. L. (1974). Biological indicators of occupational exposure to trichloroethylene. Journal of Occupational Medicine, 16, 98101.

Morgan, A., Black, A., and Belcher, D. R. (1970). The excretion in breath of some aliphatic halogenated hydro- 
carbons following administration by inhalation. Annals of Occupational Hygiene, 13, 219-233.

Müller, G., Spassovski, M., and Henschler, D. (1972). Trichloroethylene exposure and trichloroethylene metabolites in urine and blood. Archiv für Toxikologie, 29, 335-340.

Müller, G., Spassovski, M., and Henschler, D. (1974). Metabolism of trichloroethylene in man. II. Pharmacokinetics of metabolites. Archiv für Toxikologie, 32, 283-295.

Nomiyama, K. (1971). Estimation of trichloroethylene exposure by biological materials. Internationales Archiv für Arbeitsmedizin, 27, 281-292.

Nomiyama, K., and Nomiyama, H. (1971). Metabolism of trichloroethylene in human. Sex difference in urinary excretion of trichloroacetic acid and trichloroethanol. Internationales Archiv für Arbeitsmedizin, 28, 37-48.

Ogata, M., Takatsuka, Y., and Tomokuni, K. (1971). Excretion of organic chlorine compounds in the urine of persons exposed to vapours of trichloroethylene and tetrachloroethylene. British Journal of Industrial Medicine, 28, 386-391.

Perl, W., Rackow, H., Salanitre, E., Wolf, G. L., and Epstein, R. M. (1965). Intertissue diffusion effect for inert fatsoluble gases. Journal of Applied Physiology, 20, 621-627.

Pfäffli, P., and Backman, A-L. (1972). Trichloroethylene concentration in blood and expired air as indicators of occupational exposure. A preliminary report. Work-Environment-Health, 9, 140-144.

Roach, S. A. (1966). A more rational basis for air sampling programs. American Industrial Hygiene Association Journal, 27, 1-12.

Sato, A. (1968). Gas chromatographic determination of benzene and toluene in expired air. Medical Journal of Shinshu University, 13, 167-174.

Sato, A., and Nakajima, T. (1977). Accumulation kinetics of trichloroethylene and its metabolites excreted in urine (to be published).

Sato, A., Nakajima, T., and Fujiwara, Y. (1975a). Determination of benzene and toluene in blood by means of a syringe-equilibration method using a small amount of blood. British Journal of Industrial Medicine, 32, 210-214. Sato, A., Nakajima, T., Fujiwara, Y., and Hirosawa, K. (1974). Pharmacokinetics of benzene and toluene. Internationales Archiv für Arbeitsmedizin, 33, 169-182.

Sato, A., Nakajima, T., Fujiwara, Y., and Murayama, N. (1975b). Kinetic studies on sex difference in susceptibility to chronic benzene intoxication-with special reference to body fat content. British Journal of Industrial Medicine, 32, 321-328.

Stewart, R. D., Dodd, H. C., Gay, H. H., and Erley, D. S. (1970). Experimental human exposure to trichloroethylene. Archives of Environmental Health, 20, 64-71.

Stewart, R. D., Gay, H. H., Erley, D. S., Hake, C. L., and Peterson, J. E. (1962). Observations on the concentrations of trichloroethylene in blood and expired air following exposure of humans. American Industrial Hygiene Association Journal, 23, 167-172.

Stewart, R. D., Hake, C. L., and Peterson, J. E. (1974). Use of breath analysis to monitor trichloroethylene exposures. Archives of Environmental Health, 29, 6-13.

Tanaka, S., and Ikeda, M. (1968). A method for determination of trichloroethanol and trichloroacetic acid in urine. British Journal of Industrial Medicine, 25, 214-219.

Wagner, J. G. (1967). Method for estimating rate constants for absorption, metabolism, and elimination from urinary excretion data. Journal of Pharmaceutical Sciences, 56, 489494.

Williams, R. T. (1959). Detoxication Mechanisms, 2nd edition, pp. 29-30. Wiley: New York. 